\title{
Effect of Potassium Levels on Productivity and Fruit Quality of Tomato (Lycopersicon esculentum L.)
}

\author{
Sofonias Hagos Woldemariam \\ Department of Horticulture, Hamelmalo Agricultural College \\ P.O.Box 397 Keren, Eritrea \\ Email: sofizgreat@gmail.com
}

Sewa Lal

Department of Horticulture, Hamelmalo Agricultural College

P.O.Box 397 Keren, Eritrea

Email: sewalal@gmail.com

Daniel Z. Zelelew (Corresponding Author)

Department of Horticulture, Hamelmalo Agricultural College

P.O.Box 397 Keren, Eritrea

Email: danizeru43@gmail.com

\begin{abstract}
Mulugheta T. Solomon
Department of Science of Agriculture, Food and Environment (SAFE) University of Foggia

Via Napoli 25,71122, FG, Italy

Email: st.mulugheta@gmail.com
\end{abstract}

Received: December 9, 2017

doi:10.5296/jas.v6i1.12262
Accepted: December 26, 2017

URL: https://doi.org/10.5296/jas.v6i1.12262 


\section{Abstract}

Potassium has significant effect on quantity and quality of tomato yield because of its vital roles in photosynthesis, favoring high energy status and appropriate nutrient translocation and water uptake in plants. However, little is understood or it is being overlooked under Eritrean condition. Besides, poor soil fertility is among the major production constraints in Eritrea. The field experiment was therefore conducted to investigate the effect of potassium levels on productivity and fruit quality of tomato at Hamelmalo, Eritrea. The experiment was conducted in Randomized Complete Block Design with nine potassium levels $(0,50,100$, $150,200,250,300,350$ and $400 \mathrm{~kg} \mathrm{~K} \mathrm{~K}_{2} \mathrm{O} / \mathrm{ha}$ ) replicated thrice. Data was collected on yield and fruit quality parameters and they were subjected to one-way analysis of variance (1-way ANOVA). The results of this study revealed that potassium had significant effect in all yield and quality parameters studied. Fruit diameter, fruit weight per plant, total yield, total soluble solids, specific gravity and fruit dry matter content showed significant increase with an increase in potassium level from 0 to $150 \mathrm{~kg} \mathrm{~K} 2 \mathrm{O} / \mathrm{ha}$ and thereafter decreased while fruit moisture content was increased in the range of $150-400 \mathrm{~kg} \mathrm{~K}_{2} \mathrm{O} / \mathrm{ha}$. As a result, highest fruit weight $(1.39 \mathrm{~kg} / \mathrm{plant})$, fruit yield $(15.45 \mathrm{t} / \mathrm{ha})$, total soluble solids $\left(3.84{ }^{\circ} \mathrm{Brix}\right)$, specific gravity, (1.46) and fruit dry matter (5.68\%) were recorded from $150 \mathrm{~kg} \mathrm{~K} \mathrm{~K}_{2} \mathrm{O} / \mathrm{ha}$. Therefore it is recommended that potassium fertilizers should be used and balanced NPK fertilizers should be applied to improve yield and quality of tomato produced.

Keywords: Lycopersicon esculentum L., NPK-Fertilizers, Potassium, Quality, Yield

\section{Introduction}

Tomato (Lycopersicon esculentum L.) is one of the most important and widely grown vegetables around the world. It is economically attractive and the area under tomato cultivation is increasing daily (Naika et al., 2005). Tomato is rich source of minerals and vitamins, its distinctive nutritional attributes play an important role in reducing risk of cardiovascular and associated diseases through their bioactivity in modulating disease process pathways (Dias, 2012). Moreover, it is an important source of lycopene, which is a powerful antioxidant that acts as an anticarcinogen (Burton-Freeman and Reimers, 2011). Tomato fruits are also an outstanding source of ascorbic acid, and are main source of vitamin $\mathrm{C}$ next to citrus (Rao and Rao, 2007 and Di Matteo et al., 2010).

In Eritrea, tomato production has a long tradition among farmers. It is highly valuable and most popular cultivated vegetable crop grown throughout the country. It serves as source of the livelihood of many rural farmers both as food and cash. Farmers prefer to cultivate tomato because of its high demand in the market, good return and reasonably good yield (Asgedom et al., 2011). A positive correlation between the yields of tomato and high income to farmers when it is cultivated on large scale has also been reported by (Naqvi et al., 2014). According to Asgedom et al. (2011), however, average yield of tomato in Eritrea has remained as low as $10.4 \mathrm{t} / \mathrm{ha}$ compared to average yield of 51, 41, 36 and $34 \mathrm{Mt} / \mathrm{ha}$ in America, Europe, Asia and the world respectively (FAOSTAT, 2010). This could be due to poor soil fertility and the imbalanced application of Nitrogen-Phosphorus-Potassium (NPK) fertilizers. 


\section{Macrothink}

Tomato crop responds very well to manure and fertilizer application (Ramyabharathi et al., 2014). The potassium (K) requirements of tomato are high due to the fast growth of the plant in combination with higher fruit production (Chapagain and Wiesman 2004). However, the exact amount to be applied need to be determined based on fertility status of the soil and variety used. $\mathrm{K}$ is one of the major nutrients, essential for plant growth and development. It is involved in activation of enzymes important to energy utilization, starch synthesis, $\mathrm{N}$ metabolism and respiration. $\mathrm{K}$ plays an important role in photosynthesis, regulation of opening and closing of stomata, favors high energy status which helps in timely and appropriate nutrient translocation and water uptake in plants (Havlin et al., 2005). Ahmad et al., (2015) stated that K application significantly increased yield of tomato and $35.55 \%$ yield advantage over the control was obtained from application of $120 \mathrm{~kg} \mathrm{~K} / 2 \mathrm{O} / \mathrm{ha}$. Prajapati and Modi, (2012) also reported that K plays significant roles to enhance crop quality, disease resistance, and shelf-life of fruits and feeding values of produces. Besides, Javaria et al., (2012) founded that application of $375 \mathrm{~kg} / \mathrm{ha}$ of $\mathrm{K}_{2} \mathrm{O}$ had $27.44 \%$ and $101.23 \%$ increase of total solids and total soluble solids (TS and TSS), respectively as compared to control.

According to Negassi, et al., (2002) most farmers in Eritrea apply inorganic and some organic fertilizers to boost yield of commercial crops. A few kinds of fertilizers (DAP and Urea) are applied at relative low levels although it also varies among different farmers and area of cultivation but it remains to be below the recommended 225:112:112 kg/ha NPK rates (Hochmuth and Hanlon 2000). The most commonly used fertilizers in Eritrea are Di-ammonium Phosphate (DAP), urea and farmyard manure (Asgedom et al., 2011, Saleh et al., 2013, Ghebreslassie et al., 2014 and Zelelew et al., 2017) while application of K fertilizers is either very limited or no at all. This might be due to the hypothesis that the soil is originated from $\mathrm{K}$ rich parent material and contains adequate $\mathrm{K}$ to support crop growth (Murphy, 1968). However, recent research findings proved that $\mathrm{K}$ is deficient mineral (0.18 to $0.25 \mathrm{cmol} / \mathrm{kg}$ of soil) in Hamelmalo area (Million, 2014) which could be resulted due to erosion, frequent cultivation, over grazing and fuelwood and timber harvesting without replenishing of nutrients (Bein et al., 1996). Moreover, Zelelew et al., (2016) also recommended that $\mathrm{K}$ fertilizers should be introduced and used by the farmers in Hamelmalo (Eritrea) and other similar areas of the country to boost both yield and quality of produce. It is in the view of this background that the current study was designed to investigate the effect of potassium levels on productivity and fruit quality of tomato. 


\section{Materials and Methods}

\subsection{Site description}

An open field experiment was carried out at the experimental field of Hamelmalo Agricultural College; Hamelmalo (Eritrea) during winter season of 2015-16. The study area is located $12 \mathrm{~km}$ north of Keren at $15^{0} 52^{\prime} 18^{\prime \prime}$ north latitude, $38^{0} 27^{\prime} 55^{\prime \prime}$ east longitude, and is situated at an altitude of 1280 meters above sea level. The climate of the area is semi-arid with $460 \mathrm{~mm}$ annual rainfall and temperature range of $11.1^{\circ} \mathrm{C}$ to $34.7^{\circ} \mathrm{C}$ during the growing season. Prior to transplanting, twelve soil samples from representative areas of the experimental field were taken with the help of an auger at 0-30 $\mathrm{cm}$ depth. Composite and representative soil sample was prepared by thorough mixing the samples taken. It was air dried and then passed through $2 \mathrm{~mm}$ sieve, the soil sample was analyzed and its physico-chemical properties are shown in Tables 1 and 2.

Table 1 Physical characteristics of the upper soil $(0-30 \mathrm{~cm})$ of the experimental site.

\begin{tabular}{ccccc}
\hline \multicolumn{5}{c}{ Physical properties } \\
\hline Sand (\%) & Clay $(\%)$ & Silt $(\%)$ & Organic Matter $(\%)$ & Soil texture class \\
\hline 67.8 & 22.1 & 10.1 & 0.30 & Sandy loam \\
\hline
\end{tabular}

Table 2 Chemical characteristics of the upper soil $(0-30 \mathrm{~cm})$ of the experimental site.

\begin{tabular}{ccccccccc}
\hline \multicolumn{10}{c}{ Chemical properties } \\
\hline $\mathrm{N} \%$ & $\begin{array}{c}\mathrm{P} \\
(\mathrm{cmol} / \mathrm{kg})\end{array}$ & $\begin{array}{c}\mathrm{K} \\
(\mathrm{cmol} / \mathrm{kg})\end{array}$ & $\begin{array}{c}\mathrm{Mg} \\
(\mathrm{cmol} / \mathrm{kg})\end{array}$ & $\begin{array}{c}\mathrm{Ca} \\
(\mathrm{cmol} / \mathrm{kg})\end{array}$ & $\begin{array}{c}\mathrm{Na} \\
(\mathrm{cmol} / \mathrm{kg})\end{array}$ & $\begin{array}{c}\mathrm{CEC} \\
(\mathrm{cmol} / \mathrm{kg})\end{array}$ & $\begin{array}{c}\mathrm{EC} \\
(\mathrm{ms} / \mathrm{cm})\end{array}$ & $\mathrm{pH}$ \\
\hline 0.02 & 4.27 & 0.56 & 2 & 7 & 0.13 & 9.69 & 1.5 & 8.07 \\
\hline
\end{tabular}

EC: Soil electrical conductivity

CEC: Cation exchange capacity

\subsection{Experimental design}

The experiment was conducted in plots using Randomized Complete Block Design (RCBD) with nine treatment of $\mathrm{K}$ levels $\left(0,50,100,150,200,250,300,350\right.$ and $400 \mathrm{~kg} \mathrm{~K}_{2} \mathrm{O} / \mathrm{ha}$ ) replicated thrice. Full doses of $\mathrm{K}\left(\mathrm{K}_{2} \mathrm{O}\right)$ were applied through band method at the time of transplanting as per the treatments to each experimental plot. One month old healthy seedlings cultivar "Riogrande" were planted at a spacing of $75 \times 45 \mathrm{~cm}$ in furrow plots $(3 \mathrm{~m}$ $\mathrm{x} 3.6 \mathrm{~m}=10.8 \mathrm{~m}^{2}$ ) each. Irrigation was applied immediately after planting and subsequent irrigations were given as per the requirement of the crop. All other cultural practices were done uniformly for all the treatments.

\subsection{Data collection}

\subsubsection{Yield parameters}

Observations on yield parameters such as fruit diameter $(\mathrm{cm})$, fruit weight $(\mathrm{kg} / \mathrm{plant})$ and fruit yield (ton/ha) were recorded right after harvest from net plot area (12 plants) of each treatments. 


\subsubsection{Fruit quality parameters}

Data on specific gravity and total Soluble Solids (TSS) were determined from 100 sample fruits for each treatment by adopting weight-in-air/weight-in-water method and refractometer, respectively. Fruit dry matter and moisture content were determined using an oven and balance method.

\subsection{Data analysis}

The data obtained from each plot, were subjected to one-way analysis of variance (1-way ANOVA) using GENESTAT Software at 5\% level of significance to assess treatment effects. Significant differences between means were determined using Least Significant Difference (LSD) and the relationships between components were tested by IBM SPSS statistical packages version 20. In addition, correlation analysis was also determined.

\section{Results and Discussion}

\subsection{Yield and Yield components}

Figure 1 shows the influence of $\mathrm{K}$ application on fruit diameter $(\mathrm{cm})$. Significant difference $(p<0.005)$ was found on fruit diameter among treatments. Fruit diameter was gradually enhanced with increasing $\mathrm{K}$ levels up to $150 \mathrm{~kg} \mathrm{~K} \mathrm{~K}_{2} \mathrm{O} / \mathrm{ha}$. Maximum value $(4.76 \mathrm{~cm}$ ) was recorded from plots treated with $150 \mathrm{~kg} \mathrm{~K}_{2} \mathrm{O} / \mathrm{ha}$ and minimum fruit size $(3.71 \mathrm{~cm})$ was obtained from control. The fact that the experimental field was deficient in K content (Table 2) has influenced the crop to have positive response towards $\mathrm{K}$ applications. $\mathrm{K}$ application increases the size of fruits, especially, in soil with low to medium nutrient content (Perkins-Veazie and Robert, 2003). Similarly Amjad et al., (2014) reported that K application significantly induced fruit diameter. This could be ascribed to activation of enzymes by $\mathrm{K}$ and its involvement in adenosine triphosphate (ATP) production which is important in regulating the rate of photosynthesis which enable the plants to have more food to be stored in the fruits (Havlin, et al., 2005). ATP is also used as the energy source for many plant activities (Van Brunt and Sultenfuss, 1998) including cell divisions. Then cell division determines to a large extent the final number of cells in a fruit and thereafter the final fruit size (Lemaire-Chamley et al., 2005).

Result of the current study also indicated that fruits weight $(\mathrm{kg} / \mathrm{plant})$ was significantly influenced by potassium applications and was appreciably increased with increasing $\mathrm{K}$ levels up to $150 \mathrm{~kg} \mathrm{~K} \mathrm{~K}_{2} \mathrm{O}$ ha thereafter decreased (Figure 2). The highest fruit weight per plant (1.39 $\mathrm{kg}$ ) was obtained from the application of $150 \mathrm{~kg} \mathrm{~K} \mathrm{~K}_{2} \mathrm{O} / \mathrm{ha}$ whereas the lowest $(0.807 \mathrm{~kg})$ was recorded from $400 \mathrm{~kg} \mathrm{~K}_{2} \mathrm{O} / \mathrm{ha}$. Correspondingly Ghourab et al., (2000) stated that application of adequate $\mathrm{K}$ increases fruit weight by increasing translocation of photosynthates to fruit and water use efficiency. However, the excessive application of $400 \mathrm{~kg} \mathrm{~K}_{2} \mathrm{O} / \mathrm{ha}$ might have resulted negative influence on the fruit production capacity of the plants. This is in close agreement with previous investigation of Pervez et al., (2013) who confirmed that excessive doses of $\mathrm{K}$ has negative impacts on potato tubers weight per plant. Besides, the importance of balanced K nutrition for tomato crop was also advocated by (Zia-ul-Hassan, 2016). 


\section{Macrothink}

Results in Figure 3 further revealed that increasing potassium application from 0 to $150 \mathrm{~kg} / \mathrm{ha}$ had increased the yield of tomato $(\mathrm{t} / \mathrm{ha})$ significantly $(\mathrm{p}=<0.05)$. Plots treated with $150 \mathrm{~kg}$ $\mathrm{K}_{2} \mathrm{O} /$ ha gave maximum value $(15.45 \mathrm{t} / \mathrm{ha})$ with $67.75 \%$ yield advantage over the control $(0 \mathrm{~kg}$ $\mathrm{K}_{2} \mathrm{O} / \mathrm{ha}$ ). This is in close consistency with the finding of Iqbal et al., (2011) who concluded that $\mathrm{K}$ has significant effect on tomato yield and maximum yield (19 t/ha) was obtained from application of $130 \mathrm{~kg} \mathrm{~K}$ O/ha. In addition, Ahmad et al., (2015) reported that tomato yield was significantly increased and showed $35.55 \%$ yield advantage over the control when $\mathrm{K}$ is applied at the rate of $120 \mathrm{~kg} \mathrm{~K} 2 \mathrm{O} / \mathrm{ha}$. This could be due to the fact that sufficient supplement of $\mathrm{K}$ helps plants for efficient photosynthetic activities and translocation of photosynthates from sites of production to storage organs (Cakmak et al., 1994, Abd El-Latif et al., 2011 and Patil, 2011). The positive response of the crop to $\mathrm{K}$ application could also be attributed to the poor $\mathrm{K}$ content of the experimental field (Table 2).

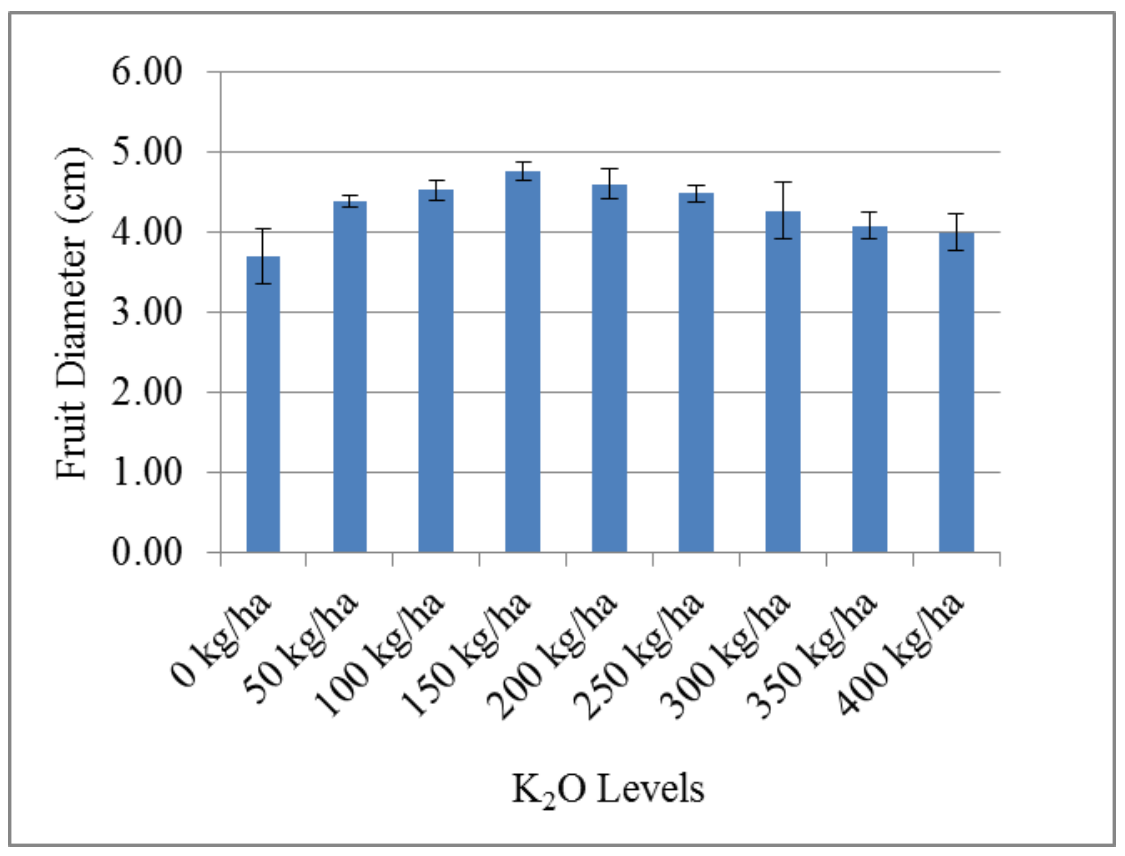

Figure 1 Effect of potassium on fruit diameter $(\mathrm{cm})$ 


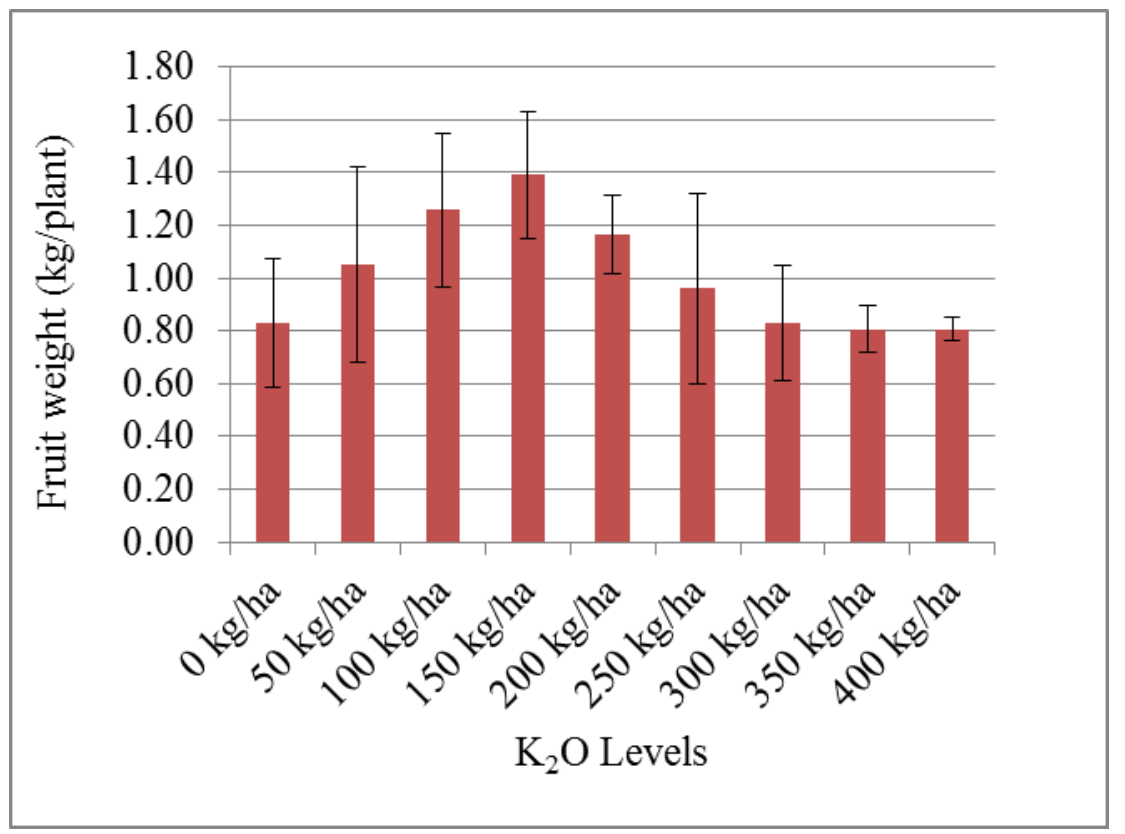

Figure 2 Effect of potassium on fruit weight (kg/plant)

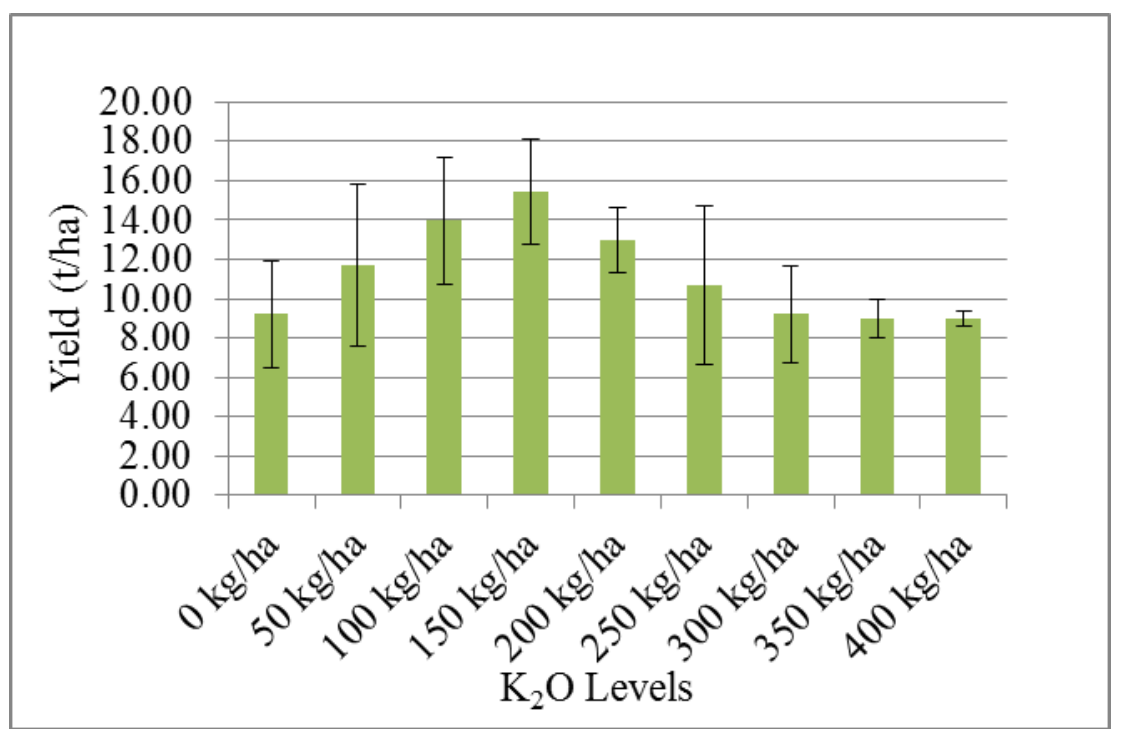

Figure 3 Effect of potassium yield of tomato (t/ha)

\subsection{Quality parameters}

Total soluble solids of tomato are predominantly sugars, which determine flavor and other fruit quality characteristic. The result presented in Figure 4 indicates that TSS was significantly influenced by potassium levels. The highest value $\left(3.84^{\circ}\right.$ brix $)$ was recorded from $150 \mathrm{~kg} \mathrm{~K} 2 \mathrm{O} / \mathrm{ha}$ while the lowest $\left(3.05^{\circ}\right.$ brix) was obtained with application of $400 \mathrm{~kg}$ $\mathrm{K}_{2} \mathrm{O} /$ ha. Similarly Javaria et al., (2012) found that TSS was significantly influenced by the application of K. TSS showed increment when $\mathrm{K}$ doses were increased up to $375 \mathrm{~kg} \mathrm{~K} 2 \mathrm{O} / \mathrm{ha}$ the author added. The increase of TSS in the fruits with the increase of $\mathrm{K}$ levels confirms that 
$\mathrm{K}$ played an important role in the configuration of quality profile in tomato fruits (Caretto et al., 2008). Besides, Wuzhong, (2002) reported that an increase of K fertilizer application increased sugar content of tomato fruit which in turn, a higher import and accumulation of sugar may enhanced TSS content in tomato fruits (Balibrea et al., 2006). In contrary to the current findings Al-Moshileh et al., (2017) reported that k application did not have significant effect on TSS of tomatoes.

The influence of $\mathrm{K}$ application on specific gravity was found to be significant. Specific gravity had shown gradual increment with increasing potassium levels up to $150 \mathrm{~kg} \mathrm{~K}_{2} \mathrm{O} / \mathrm{ha}$ then after decreased. Maximum value (1.46) was obtained from application of $150 \mathrm{~kg} \mathrm{~K}_{2} \mathrm{O} / \mathrm{ha}$ while plots treated with $400 \mathrm{~kg} \mathrm{~K} \mathrm{~K}_{2} \mathrm{O} / \mathrm{ha}$ gave the lowest (1.10) mean value (Figure 5). Consistent to the current results, Zelelew and Ghebreslassie (2016) reported that application of $\mathrm{K}$ fertilizer had significant influence on specific gravity of potato tubers and maximum (1.11) was obtained from $150 \mathrm{~kg} \mathrm{~K} 2 \mathrm{O} / \mathrm{ha}$. Similarly application of $150 \mathrm{~kg} \mathrm{~K} 2 \mathrm{O} / \mathrm{ha}$ yielded highest fruit size and fruit weight per plant (Figures 2 and 3) which might have a positive effect on specific gravity which is closely correlated with fruit size and weight (Tigist et al., 2012). Application of sufficient $K$ also decreases dark respiration leading to more deposition of photosynthates in the sink (Bergmann, 1992 and Havlin et al., 2005) that ultimately increased fruit size and specific gravity of tomato fruits.

Fruit dry matter content had increased significantly with increasing $\mathrm{K}$ application up to 150 $\mathrm{kg} \mathrm{K} \mathrm{K}_{2} \mathrm{O} /$ ha and then decreased (Figure 6). The highest and lowest dry matter content $(5.68 \%$ and $4.53 \%$ ) were obtained from applications of 150 and $400 \mathrm{~kg} \mathrm{~K}_{2} \mathrm{O} / \mathrm{ha}$, respectively. In line to the current result decreased in dry matter content of tomato and sweet pepper fruits was reported when potassium was applied above $225 \mathrm{Kg} / \mathrm{ha}$ (Wuzhong, 2002). On potassium deficient soils, dry matter percentage increases with increasing $\mathrm{K}$ doses but it is only up to the rate required for optimum yield (McNabnay et al., 1999). Likewise soil fertility of the current experimental field was deficient in $\mathrm{K}$ content (Table 2) resulted for positive response up to $150 \mathrm{~kg} \mathrm{~K} \mathrm{~K}_{2} \mathrm{O} / \mathrm{ha}$ which might be the optimum level for that particular area. The result was supported by Panique et al., (1997) who reported that reductions in dry matter content occurred only if high rates of potash are applied.

With regard to fruit moisture content, potassium treatment was found to have statistically significant effect. Opposite to fruit dry matter content, fruit moisture content had increased more in the range of $150-400 \mathrm{~kg} \mathrm{~K} 2 \mathrm{O} / \mathrm{ha}$. Maximum fruit moisture content (95.47\%) was obtained from the application of $400 \mathrm{~kg} \mathrm{~K}_{2} \mathrm{O} / \mathrm{ha}$ (Figure 7). The result of this current experiment is supported by the findings of (Bergmann, 1992) who reported that with the application of potassium, the water contents of the plasma volume were found to be influenced, thus increased the water contents of fleshy storage tissues as to reduce the dry matter content. This could be due to the vital role $\mathrm{K}$ in water use efficiency of crops, maintaining the turgidity of plant cells and amount of water in plant cells so as to increase the amount of water in plant organ like fruits (Abd El-Latif et al., 2011). 


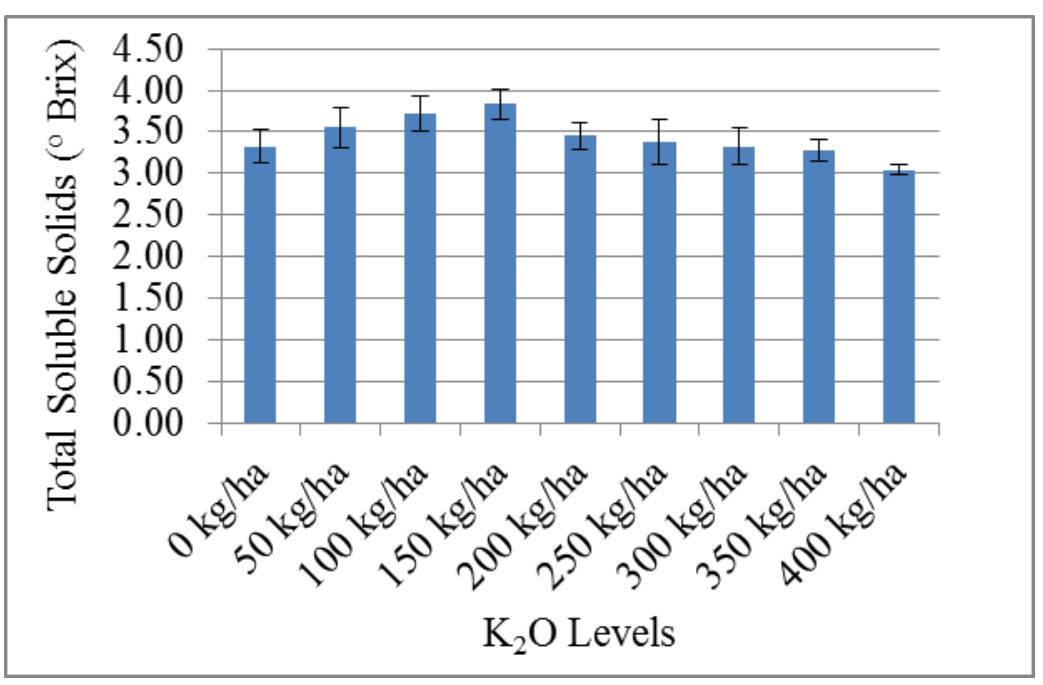

Figure 4 Effect of potassium on Total soluble solids $\left({ }^{\circ}\right.$ Brix $)$

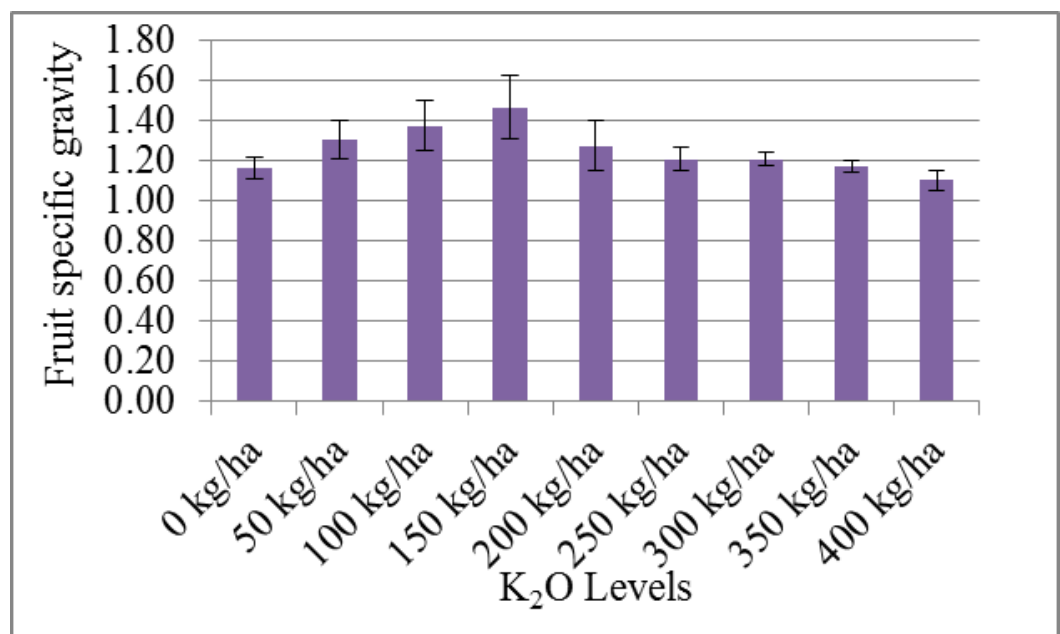

Figure 5 Effect of potassium on fruit specific gravity 


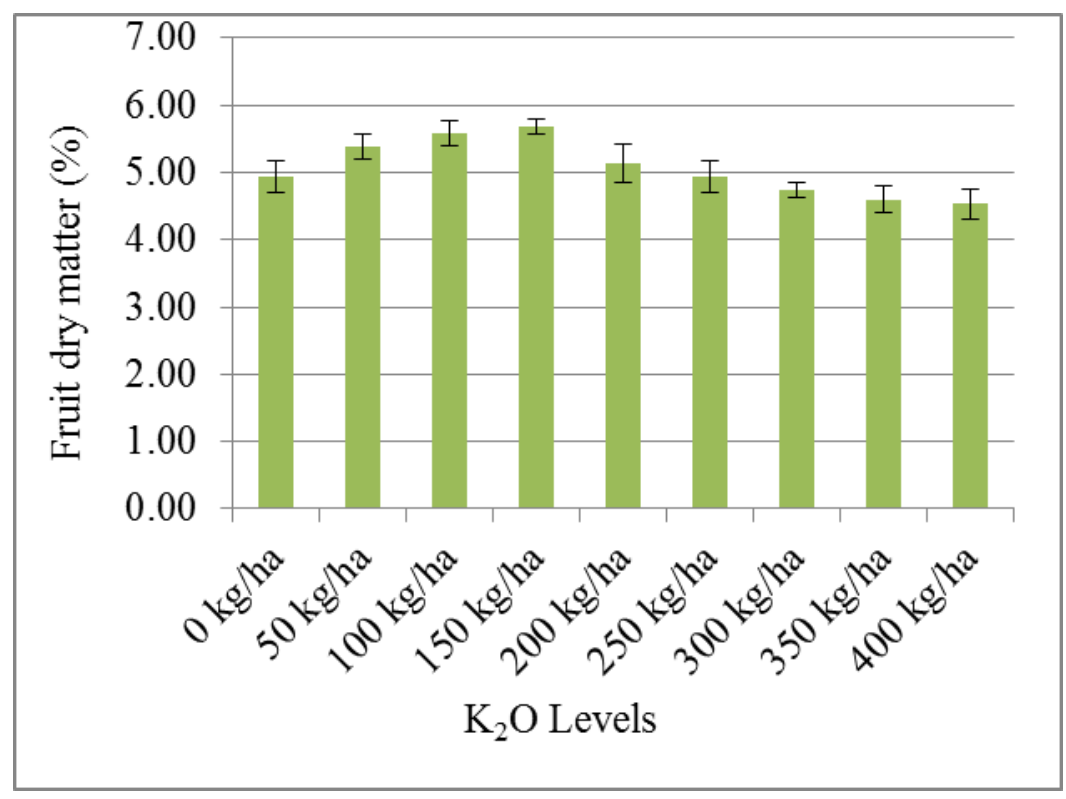

Figure 6 Effect of potassium on fruit dry mater content (\%)

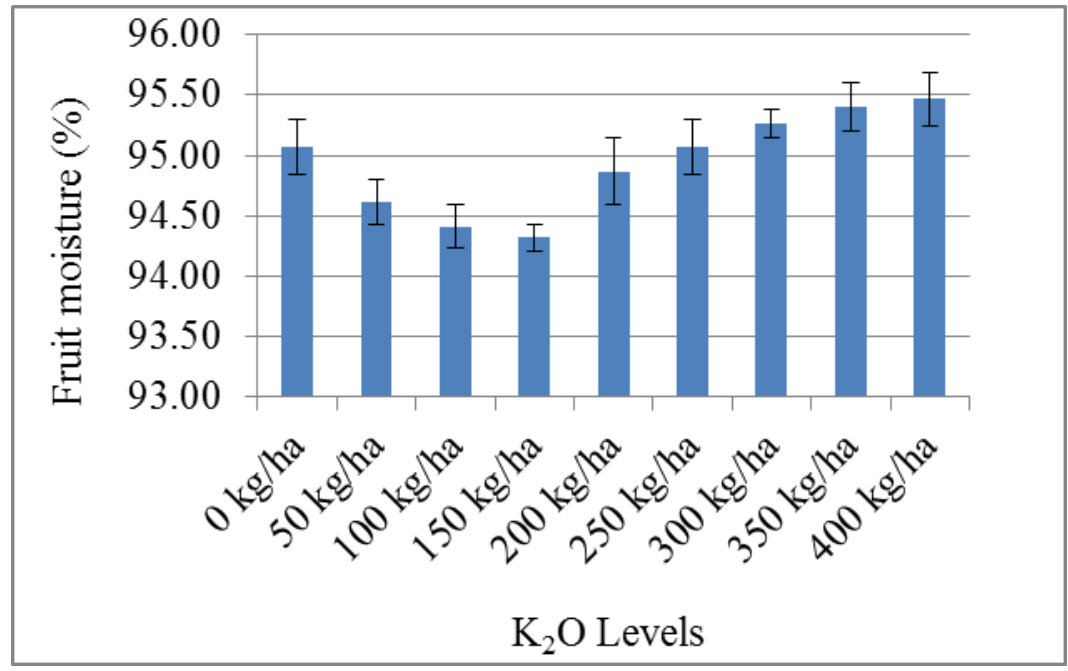

Figure 7 Effect of potassium on fruit moisture content (\%)

\subsection{Correlation among Potassium, Yield and Quality Parameters}

Correlation analysis result revealed that, $\mathrm{K}$ had positive and significant correlation with fruit diameter $(r=0.066)$, fruit weight per plant $(r=0.315)$ and total fruit yield $(r=0.315)$. Similar positive correlation of $\mathrm{K}$ with fruit weight per plant and fruit diameter was reported by (Amjad et al., 2014). This indicates that increasing $\mathrm{K}$ levels results an increase on fruit diameter; fruit weight per plant and total fruit yield. This is due to the significant role of $\mathrm{K}$ in carbohydrate formation and transformation and movement of photosynthates from sites of production to storage organs (Cakmak et al., 1994, Abd El-Latif et al., 2011 and Patil, 2011). Fruit diameter was also positively correlated with fruit weight per plant $(r=0.599)$ and total fruit yield $(r=$ 
0.599). These positive correlations implies that for every addition of tomato fruit size there was an increase on fruit weight produced per plant and then ultimately increased overall fruit yield. Likewise, total fruit yield was found to be positively correlated with TSS $(r=0.577)$, fruit specific gravity $(r=0.667)$ and fruit dry matter $(r=0.688)$. The result further proved that potassium application had positive correlation with TSS $(r=0.441)$, fruit specific gravity $(r=0.395)$ and fruit dry matter $(r=0.600)$. This could be due to the active role of $\mathrm{K}$ in increased sugar content of tomato fruit Wuzhong, (2002) which in turn a higher import and accumulation of sugar may enhanced TSS content in tomato fruits (Balibrea et al., 2006).

\section{Conclusion}

It is concluded that application of $\mathrm{K}$ fertilizer has significant and positive influence on yield and fruit quality parameters of tomato. There were positive correlations among $\mathrm{K}$, yield and fruit quality parameters. Highest fruit weight $(1.39 \mathrm{~kg} / \mathrm{plant})$, fruit yield $(15.45 \mathrm{t} / \mathrm{ha})$, total soluble solids $\left(3.84^{\circ}\right.$ Brix), specific gravity, (1.46) and fruit dry matter (5.68) were recorded from $150 \mathrm{~K}_{2} \mathrm{O} \mathrm{kg} / \mathrm{ha}$. It is therefore recommended that fertilizer package policy of the country need to be revised, K fertilizers should be introduced and balanced NPK fertilizers should be applied to improve yield and quality of tomato produce.

\section{Acknowledgment}

The authors are thankful to the Hamelmalo Agricultural College in collaboration with Eritrean National Commission for Higher Education for funding and facilitating the research project.

\section{References}

Abd El-Latif, K.M., Osman, E.A.M., Abdullah, R. and Abdel Kader, N. (2011). Response of Potato Plants to Potassium Fertilizer Rates and Soil Moisture Deficit. Advances in Applied Science Research, 2, 388-397.

Ahmad, N., Sarfraz, M., Farooq, U., Arfan-ul-Haq, M., Mushtaq, M.Z. and Ali, M.A. (2015). Effect of potassium and its time of application on yield and quality of tomato. International Journal of Scientific and Research Publications, 5(9): 1-4.

Al-Moshileh, A.M., Errebhi, M.A. and Obiadalla-Ali, H.A. (2017). Effect of potassium fertilization on tomato and cucumber plants under greenhouse conditions. Bioscience research, 14(1): 68-74.

Amjad, M., Akhtar, J., Anwar-Ui-Haq, M., Imran, S. and Jacobsen, S. (2014). Soil and foliar application of potassium enhances fruit yield and quality of tomato under salinity. Turkish Journal of Biology, 38: 208-218. https://doi.org/10.3906/biy-1305-54

Asgedom, S., Struik P.C., Heuvelink Ep. and Araia, W. (2011). Opportunities and constraints of tomato production in Eritrea. African Journal of Agricultural Research, 6(4): 956-967.

Balibrea, M.E., Martínez-Andújar, C., Cuartero, J., Bolarín, M.C. and Pérez-Alfocea, F. (2006). The high fruit soluble sugar content in wild Lycopersicon species and their hybrids with cultivars depends on sucrose import during ripening rather than on sucrose metabolism. 
Functional Plant Biology, 33(3): 279-288. https://doi.org/10.1071/FPO5134

Bein, E., Habte, B., Jaber, A., Ann Birnie and Bo Tengnas. (1996). Useful Trees and Shrubs in Eritrea: Identification, propagation and management for agricultural and pastoral communities. Reginal Soil Consrvation Unit, Nirobi, Kenya.

Bergmann, W. (1992). Nutritional disorders of plants development, visual and analytic diagnosis. Gustav Fischer, Jena.

Burton-Freeman, B. and Reimers, K. (2011). Tomato Consumption and Health: Emerging Benefits. American Journal of Lifestyle Medicine, 5(2): 182-191.

https://doi.org/10.1177/1559827610387488

Cakmak, I., Hengeler, C. and Marschner, H. (1994). Partitioning of shoot and root dry matter and carbohydrates in bean plants suffering from phosphorus, potassium and magnesium deficiency. Journal of Experimental Botany, 45(9): 1245-1250.

https://doi.org/10.1093/jxb/45.9.1245

Caretto, S., Parente, A., Serio, F. and Santamaria, P. (2008). Influence of Potassium and Genotype on Vitamin E Content and Reducing Sugar of Tomato Fruits. Hortscience, 43(7): 2048-2051.

Chapagain, B.P., and Wiesman, Z. (2004). Effect of potassium magnesium chloride in the fertigation solution as partial source of potassium on growth, yield and quality of greenhouse tomato. Scientia Horticulturae, 99, 279-288. https://doi.org/10.1016/S0304-4238(03)00109-2

Dias, J.S. (2012). Nutritional Quality and Health Benefits of Vegetables: A Review. Food and Nutrition Sciences, 3, 1354-1374. http://dx.doi.org/10.4236/fns.2012.310179

Di Matteo, A., Sacco, A., Anacleria, M., Pezzotti, M., Delledonne, M., Ferrarini, A., Frusciante, L. and Barone, A. (2010). The ascorbic acid content of tomato fruits is associated with the expression of genes involved in pectin degradation. BMC Plant Biology, 10:163. https://doi.org/10.1186/1471-2229-10-163

FAOSTAT, (2010). The food and agriculture organization of the United Nations statistical database: http://faosta.fao.org/default.aspx?lang=en

Ghebreslassie, B.M., Githiri, S.M., Tadesse, M. \& Kasili. W.R. (2014). Diagnostic Survey on Potato Production Practices in Eritrea. Journal of Agricultural and Biological Science, 9(12): 444-453.

Ghourab, M.H.H., Wassel, O.M.M. and Raya, N.A.A. (2000). Response of cotton plant to foliar application of (Pottasin-P) TM under two levels of nitrogen fertilizer. Egypt J. Agric. Res., 78, 781-793.

Havlin, J.L., Beaton, J.D., Tisdale, S.L. and Nelson, W.L. (2005). Soil Fertility and Fertilizers: an introduction to nutrient management ( $7^{\text {th }}$ ed.). Pearson Educational, Inc, NJ, USA.

Hochmuth, G.J., \& Hanlon, E.A. (2000). IFAS standardized fertilization recommendations for vegetable crops.Circular 1152. University of Florida, Institute of Food and Agricultural 
Sciences, Gainesville, FL.

Iqbal, M., Niamatullah, M., Yousaf, I., Munir, M. and Khan, M.Z. (2011). Effect of nitrogen and potassium on growth, economical yield and yield components of tomato. Sarhad J. Agric., 27(4): 545-548.

Javaria, S., Khan, M.Q. and Bakhsh, I. (2012). Effect of potassium on Chemical and Sensory Attributes of Tomato Fruits. The Journal of Animal \& Plant Sciences, 22(4): 1081-1085.

Lemaire-Chamley, M., Petit, J., Garcia, V., Just, D., Baldet, P., Germain, V., Fegard, M., Mouassite, M., Cheniclet, C. and Rothan, C. (2005). Changes in transcriptional profiles are associated with early fruit tissue specialization in tomato. Plant Physiol., 139(2): 750-769.

https://doi.org/10.1104/pp.105.063719

McNabnay, M., Dean, B. B., Bajema, R. W. and Hyde, G. M. (1999). The effect of potassium deficiency on chemical, biochemical and physical factors commonly associated with black spot development in potato tubers. American Journal of Potato Research, 75, 53-60.

https://doi.org/10.1007/BF02855200

Million, W.T. (2014). Status and distribution of macro nutrient (NPK) in soil of Hamelmalo area. MSc. Thesis submitted to Hamelmalo Agricultural College, Keren, Eritrea.

Murphy, H.F. (1968). A report on the Fertility status and other data on some soils of Ethiopia. Bulletin, College of Agriculture, Haile Sellasie I University, Experiment station, Dire Dawa, Ethiopia, No 44.

Naika, S., Jeude, J., Goffau, M., Hilmi, M. and Van Dam, B. (2005). Cultivation of tomato: production, processing and marketing. Agromisa Foundation and CTA, Wageningen, the Netherland.

Naqvi, S.D.Y., Tesfalem, A., Tesfazghi, B., Asfeha, G. and Mangesteab, R. (2014). Survey on economical important fungal disease of tomato in sub-Zoba Hamelmalo of Eritrea. Review of Plant Studies, 1(2): 39-48. https://doi.org/10.18488/journal.69/2014.1.2/69.2.39.48

Negassi, A., Bein, E., Ghebru, K. and Tengnäs, B. (2002). Soil and Water Conservation Manual for Eritrea. RELMA Technical Hand-book No. 29. Regional Land Management Unit, Swedish International Development Cooperation Agency. Nairobi, Kenya.

Panique, E., Kelling, K.A., Schulte, E.E., Hero, D.E., Stevenson, W. R. and James, R.V. (1997). Potassium rate and source effects on potato yield, quality and disease interaction. American Potato Journal, 74, 379-398. https://doi.org/10.1007/BF02852777

Patil, R.B. (2011). Role of potassium humate on growth and yield of soybean and black gram. International Journal of Pharma and Bio sciences, 2(1): 242-246.

Perkins-Veazie, P. and Roberts, W. (2003). Can potassium application affect the mineral and antioxidant content of horticultural crops? American Society Agronomy Production. Symposium on Fertilizing Crops for Functional Foods, 2/1-2/6.

Pervez, M.A., Ayyub, C.M., Shabeen, M.R. and Noor, M.A. (2013). Determination of 


\section{Macrothink}

Journal of Agricultural Studies

ISSN 2166-0379

2018, Vol. 6, No. 1

Physiomorphological Characteristics of Potato Crop Regulated by Potassium Management. Pakistan Journal of Agricultural Sciences, 50(4): 611-615.

Prajapati, K. and Modi, H.A. (2012). The Importance of Potassium in Plant Growth - a Review. Indian Journal of Plant Science, 1, 177-186.

Ramyabharathi, S.A., Shanthiyaa, V., Sankari Meena, K. and Raguchander, T. (2014). Nutrient deficiencies management for tomato and potato. An ebook on nutrient disorder. Smashwords, Inc. USA.

Rao, A.V. and Rao, L.G. (2007). Carotenoids and Human Health. Pharmacological Research, 55(3): 207-216. https://doi.org/10.1016/j.phrs.2007.01.012

Saleh, B.K., Nyende, A.B., Kasili, R., Mamati, E. and Araia, W. (2013). Current Status and Future Opportunities of Pepper Production in Eritrea. ARPN Journal of Agricultural and Biological Science, 8(9): 655-672.

Tigist, A., Workneh, T.S. and Woldetsadik, K. (2012). Effects of variety on yield, physical properties and storability of tomato under ambient conditions. African Journal of Agricultural Research, 7(45): 6005-6015. https://doi.org/10.5897/AJAR11.1215

Van Brunt, J.M. and Sultenfuss, J.H. (1998). Functions of Potassium in plants. Better crops, 82(3): 4-5.

Wuzhong, N. (2002). Yield and Quality of Fruits of Solanaceous Crops as Affected by Potassium Fertilization. Better Crops International, 16(1): 6-8.

Zelelew, D.Z. and Ghebreslassie, B.M. (2016). Response of Potato Varieties to Potassium Levels in Hamelmalo Area, Eritrea. Journal of Plant Studies, 5(1): 11-19.

Zelelew, D.Z., Kidane, T.T., Naqvi, S.D.Y. and Suryanarayana A.K. (2017). Potential and constraints of garlic production in Southern region, Eritrea. ARPN Journal of Agricultural and Biological Science, 12(8): $249-257$.

Zelelew, D.Z., Lal, S., Kidane, T.T. and Biniam, M.G. (2016). Effect of Potassium Levels on Growth and Productivity of Potato Varieties. American Journal of Plant Sciences, 7, 1629-1638. http://dx.doi.org/10.4236/ajps.2016.712154

Zia-ul-Hassan, Kubar., K.A., Chhajro, M.A., Kandhro, M.N., Jamro, G.M., Talpur, K.H. and Talpur, N. (2016). Response of Tomato (Lycopersicon esculentum L.) at Varying Levels of Soil Applied Potassium. Journal of Basic \& Applied Sciences, 12, 198-201.

\section{Copyright Disclaimer}

Copyright for this article is retained by the author(s), with first publication rights granted to the journal.

This is an open-access article distributed under the terms and conditions of the Creative Commons Attribution license (http://creativecommons.org/licenses/by/4.0/). 